\title{
Batik Industry in Banyuwangi: Model of Craftsmen Community and Prospects
}

\author{
Ni’matul Istiqomah $^{1^{*}}$, Nur Anita Yunikawati ${ }^{2}$, Magistyo Purboyo Priambodo ${ }^{3}$, \\ Emma Yunika Puspasari ${ }^{4}$, Windra Irdianto ${ }^{5}$, Marzanah A Jabbar ${ }^{6}$, Fatimah Sidi ${ }^{7}$ \\ 1, 2, 3,4,5 Universitas Negeri Malang, Malang, Indonesia \\ ${ }^{6,7}$ Universiti Putra Malaysia, Selangor, Malaysia \\ "Corresponding author. Email: nimatul.istiqomah.fe@um.ac.id
}

\begin{abstract}
The purpose of writing this article is to analyse the state of the batik industry in Banyuwangi Regency. The writing of this article also aims to analyse the effectiveness of the batik community and business opportunities to improve the community's economy. Research is using the methods of qualitative descriptive with Mechanical retrieval of data namely in- depth interviews, observation, and documentation. The result of this research is a model for the formation of a batik craftsman community which aims to increase the prospect of batik production in the village of Tampo. Community artisan's batik needs to be formed to the intensity of the meeting and the purpose of the formation to create the conditions of a community are good.
\end{abstract}

Keywords: Batik banyuwangi, Community of craft men model, Industrial batik.

\section{INTRODUCTION}

Batik, as one of the cultures and richness typical of Indonesia, have a variety of motives that are quite interesting in every region in Indonesia. In addition to the culture and richness of nature in Indonesia, batik is also a style of clothing that is famous in Indonesia [1]. As one of the wealth of culture of the nation of Indonesia, batik can give a contribution from the terms of the economic society is the opportunity of business just for craftsmen batik. Because it's, business batik is very suitable to be developed into an industry that is an industry of micro small and medium. This is quite interesting because of the richness of Indonesian culture it can raise the economic life of the local community.

Batik has a unique design from each region. For example, Banyuwangi with batik called Batik Gajah Oling. Banyuwangi besides 're doing development in the field of tourism, also seeks to increase the diversity of cultural and economic communities through various events conducted each year. As an example to introduce batik to the rating of domestic and foreign, banyuwangi held the Banyuwangi Batik Festival (BBF). One of the agenda is used to introduce the culture of the gained Batik Gajah Oling to the public area.
As one of the 14 industries creative in Indonesia, Industry cough role in displaying the culture typical of Indonesia [2] . In addition to the role of the introduction of the culture of the nation Indonesia, industries batik and weaving in the year 2016 is able to provide contribution quite high towards the economy of national standard of export. With the high contributions given, the Ministry of Industry seeks to continue to boost the performance of solid work by focusing on the absorption power of work.

The batik industry in Indonesia is categorized as a small and medium-sized industry (UKM) in which every area that has the potential for batik production is one of the livelihoods for the local community. When this, Banyuwangi was one of the areas that have the potential batik quite high, in addition to increasing the role and the community in recognition of culture as well to support the economy community locally. Along with the increase in the sector of tourism in the district of Banyuwangi, the popularity of batik is also increasing. From this, we can understand the existence of a continuity between the tourism sector and the prospects for batik in the future. As one of the regional assets, it is easier for local governments through regional autonomy to provide their own regional policies and understanding to be developed [3]. 
Destinations to travel in Banyuwangi the moment it has grown rapidly started to raise awareness of the community to establish a prospect that capitalizes the potential of the area. Tampo village as one of the areas in Banyuwangi district that has the potential for batik production is preparing to make the prospect of a batik tourism village, especially in the southern Banyuwangi area. With the capital production of principal that is Batik Gajah Oling, people began to pioneer the business independently with a capital of knowledge that is gained from educational outlet batik predecessor. From this explanation, it appears that the community really cares about the potential of the local area and is starting to realize that this potential can be used as a source of livelihood and to improve the economy of the people of the village of Tampo.

Development of economic society (CED) is one of the approaches to overcoming poverty, especially in the area of urban [1]. The strategy in community economic development (CED) is market-based. Economic development that involves the community is increasingly being carried out and used as one of the programs to support the local regional economy.

Currently, craftsmen Batik Gajah Oling in the Tampo Village always get orders from consumers, especially consumers local because according to the view of society Banyuwangi, Tampo Village is one of the villages producing batik, especially in the area Banyuwangi south. Many programs in the government area Banyuwangi are required to use Batik Gajah Oling for employees on Monday. This program is quite helpful for the craftsmen to increase the order for the Batik Gajah Oling. With many orders addressed to each of craftsmen batik such, shows the potential of which is quite high. Will however, the potential of which is rated good have still not been coordinated with either through a community of craftsmen batik. The community of batik craftsmen in the village of Tampo still does not really care about the importance of the community, especially the batik craftsmen community.

The formation of batik communities is based on the participation of the community, especially batik craftsmen, to be able to play a role in increasing awareness and social capital. Capital social into things that are very important especially in the development of Indonesia as one of the developing countries. Besides that, batik as one of prospects of eye livelihoods of the community Tampo Village, very appropriate if developed into a form of business SMEs valuable cultural and economic high

\section{METHOD}

This research uses research and development methods ( R \& D). The purpose of using this method is to provide a model for community development of batik craftsmen. The location of this research is in Tampo village, cluring sub-district, Banyuwangi regency, East Java. The sample was carried out purposefully, namely the Banyuwangi batik craftsmen in the Tampo village as many as 4 batik craftsmen namely Virdes, Tatsaka, Tresno, Najiha Batik. The stages in this research are:

2.1. Preliminary. Namely conducting field studies with observations of the batik craftsmen community.

2.2. Designing a model. This stage is carried out after knowing about the conditions in the field, namely about the condition of the batik craftsmen community that has not been maximally implemented.

2.3. Empiric study. At this stage the researcher conducted an empirical study by conducting indepth interviews with batik craftsmen.

2.4. The final stage in this research is to disseminate the prototype model for the development of the batik craftsmen community.

Tampo village as one of the batik producing villages in Banyuwangi is a consideration for researchers to determine the research location. Data collection techniques through primary and secondary data in the form of observation, literature study, in-depth interviews, and Focus Group Discussion (FGD). The analysis was carried out in a descriptive qualitative manner to explain the importance of the batik craftsmen community and to describe the model for the formation of the batik craftsmen community in accordance with the phenomena in the field.

\section{RESULTS AND DISCUSSION}

\subsection{An overview of the village of tampo as a village producing banyuwangi batik}

Tampo Village is one of the villages located in the sub district Cluring district of Banyuwangi Java east. Tampo village is famous for producing Banyuwangi batik which is quite well known by the people of Banyuwangi Regency. Based on data from the Banyuwangi Micro, Small and Medium Enterprises (UMKM), some batik craftsmen are scattered in the Tampo village so that this village is called the village of batik. Tampo village has the potential for people who care about the existence of Banyuwangi batik as one of the cultures of the Indonesian nation. Batik Gajah Oling is a batik production of Tampo Village which are quite famous with motifs typical of the district of Banyuwangi. The Batik Gajah Oling motif is known as the oldest and original motif. This motif is also believed to be a form of power that grows in the identity of the Banyuwangi community [4].

In the Tampo Village there are outlets where batik became a pioneer of the development of batik in the Tampo Village. Studio batik that is Virdes. Virdes is a pioneer developer of batik in the Tampo Village who 
also became the inspiration for the community to develop the potential of local communities.

Virdes established originated from the owner of the opening of business of batik in Bali since the year 1984. The owner virdes then moved to the village of Tampo in the year 2000 and at the same time was the first to become a pioneer of batik in the Tampo Village.

In addition to studio batik virdes, Tresno is one of the studio batik is quite well-known in the Tampo Village which stood since the year 2014. Initial establishment of batik Tresno originated from becoming employees virdes. Because he already has the skills and experience in batik production and marketing, the owner decided to open a batik shop with experience as a virdes employee. Based on the results of observations that were conducted by researchers before, some craftsmen batik in the Tampo Village a former employee virdes which have gained experience of the production of batik.

Next is the Tatsaka batik which is one of the famous batik studios in the village of Tampo. Batik Tatsaka started up in 2016. The owner batik Tatsaka, a former employee virdes the same as the owner of batik Tresno. Own Batik Tatsaka began to love the wisdom of locals, especially batik since the stimulus from the government to hold a festival batik every year. The Batik Festival in Banyuwangi of the year 2019 has been running for 7 years. Tatsaka batik was established with private capital.

In addition to the three galleries batik -known in the village Tampo such, many outlets other batik which was established by the community village local. Community villages that have a skill in making batik feel that the activities of the production of batik is very influential significantly towards improvement of the economic society. Because of it, in addition to a sense of love towards the culture of the nation, the prospect of crafting batik can boost the sustainability of the business of micro small and medium-sized in the community. By thus, it can improve the condition of the economy of society.

\subsection{The development of the batik industry in the village of tampo}

The development of batik is currently being popular among local people and people in other areas. According to the results of our interviews, the development of batik is very perspective and sustainable. It is said to be prospective because batik production in Tampo village is never empty of orders. In addition, the local government program that requires wearing batik uniforms when working is one of the prospects that can increase orders and will automatically increase local people's income and economy.

Community empowerment is an interesting thing for further research because it will increase professionalism and involve the community to produce a more effective output [5].

Seeing the early history of the development of batik in the village of Tampo, where there was only one pioneer of the batik workshop, namely virdes, the prospect of batik is considered less developed and can even be said to have stopped. Batik market is considered less evolved. However, the situation changed at the time when the batik outlet was opened, it was increasingly in demand by the public. With the development of this, causing a lot of innovation production and demanding the craftsmen to always upgrade motifs that are able to boost sales.

Currently, pandemic covid be one of the reasons for the major changes of the various sectors either the sector of tourism, industry, even to the sector of Education. Industry small micro and medium such as industry batik is quite confident with the increase in the production of batik will but until the pandemic covid time of this, the increase in the production of batik tends to decrease. From the data of Focus Group Discussion (FGD), this decrease was caused, among others:

a. Downs of travellers who visit Banyuwangi so influential on the result of the sale of batik.

b. Many employees have been temporarily dismissed to prevent the spread of the covid 19 virus

c. Demand will batik from outlets batik relatively decreased because people are going to book a batik for activities had to postpone the activities mentioned.

The development of production of the industry of batik is the average increase over the five years past. However, this development is not always stable, many conditions fluctuate due to competition between shop owners and batik production houses. But the competition is not so impacted because each voter outlet does not ever stop receiving orders but orders from agencies of government as well as individuals (home staircase). Developments which tend to steady it lasts for many years until finally in the year 2020 affected by the pandemic covid 19, which makes production slowed due to lack of orders.

The development of the production of batik for several years past are quite fluctuating also influenced by several factors, namely:

a. Held a batik festival agenda which led to an increase in demand

b. High raw materials such as dyes and water glass

c. A Tampo fair was held to increase production

Not to be denied that virdes is one of the studio batik became a pioneer production of batik in the Tampo Village. Employees are taken from the Tampo village community who are given training to be able to produce batik. The phenomenon is becoming the beginning of their interest in the community to develop the potential of the community to develop the productivity of batik. The development of local batik craftsmen in the Tampo 
village continues to grow along with the number of virdes employees who already have skills in producing batik. With a capital of the skills of the people who ever worked in virdes they began to open outlets in homes there. Starting with the production itself until the end requires a power of work.

According to the results of interviews with the head of Tampo village, the employees who work at the batik outlet range from 5-10 employees. Skills possessed by employees continue to be honed at the outlet of production but there are workers who come from outside the area. It is due because they lack skill in making batik. Stand batik are the Tampo Village is focused on management in individual and rated very significant in increasing the income of residents of the village.

\subsection{Development and empowerment community}

Before we explore the importance of community batik, we will understand the first advance on the meaning of community. Community is defined as a unit or entity that is organized in groups in order to achieve the interests of Commons. Can be interpreted also in daily life we see people who live in groups both large and small and have a dependency on each other to meet the interests of life. The concept of community here is having social relations.

In the ABCD (Asset-Based Community Development) theory, it is found that this theory can include several other theories such as psychological, namely about individual assets and social theory, namely about collective assets [6]. In empowering the local community, each individual has the awareness to apply several things that can improve economic life, such as becoming a batik craftsman. Meanwhile, seen from social theory, society is able to survive by giving priority to social competence, resilience and skills to commitment. And both of these things, have appeared in the Tampo village's community.

In a sociological perspective, a community is seen as a citizen who is distinguished from society where members of the community have shared needs and if there is no shared need then we cannot name the community. The formation of the community is included into one of the empowerment of the community. Where the empowerment of communities involves various elements of planning, organizing, development activity which aims for the benefit of Commons to improve the standard of living. Implementation of the empowerment of the people can be started from the participation or involvement of the community. The development community is considered as the solution of various problems that arise in the community, especially those relating to the life of the social economy. The role and the community is one of the elements essential to the development potential of the area.

Society as one of the parties whose role is important in the enhancement of economic society should be a racket village, required capital social form of selfreliance, concern, and cooperation between communities in developing the potential of the area. Active community participation can create community empowerment [1]. The elements that are contained in the empowerment of the people described by the definition of operational following.

Capital physical (physical capital). Regarding physical assets and facilities that support a joint venture. Physical capital can include agricultural production facilities, physical facilities and infrastructure (education, health, economy, communication, and transportation) [1]. In the Tampo Village as the village that the centre evolved into a rural tourist facilities are already available both at the level of the village up to the sub-district. Amenities physical that can support the community Tampo Village to improve the quality of life as one of the supporters of empowerment in the local community.

Human capital associated with the ability to perform activities with emphasis on the indicator level of education, level of health, and interaction amongst. Due Tampo Village has a facility that is physical, then the capital of the society can be supported on the strengthening of the capital physically. This can be seen from the skills of the community in developing good production to meet the economic needs of the family [1]. Besides the skills in establishing communication between the community can be established with both. Interaction with the other to support the marketing is also seen with their often held exhibition of the works of batik from Tampo Village.

The following is a participatory community planning process:
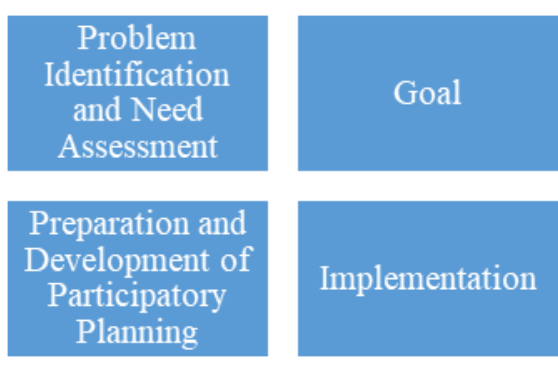

Evaluation

Figure 1 Participatory planning process, Huraerah, A. (2008).

The process of planning participatory that can be used as a step to form a community economy. In a case study in the village of Tampo, this model could be 
developed to form a community of batik craftsmen. The community that was formed in Banyuwangi district has not had a maximum function. The function of the community artisan's batik is to minimize the possibility of unfair competition. Because the purpose of the establishment of a community is a relationship that is mutual dependence to meet the needs of the people in the community. Community involvement is used to encourage community development. [7]

\subsection{Batik community development model}

This batik community development model is based on the participatory planning process of the Tampo village community. Based Step- step -par unannounced the public as the beginning of the formation of a community of craftsmen batik are as follows.

\subsubsection{Identity of the problem and need assessment}

Based on book development community, the identification of the problem is based on the assessment needs dab is defined as a deficiency in which people attempt to overcome the problems that are in the midst of society, especially problems of the economy are concerns welfare. There is information that is used to assess the needs (needs assessment) is Profile communities. Tampo Village concerning age, ethnicity, religion, region of origin, population, long life. Seeing the state of demographics such, the community Tampo Village derived from ethnic that biggest is the population of native banyuwangi and Java. Data demographics to identify problems and need assessment is also needed to note the pattern of population such as the economy, jobs, the pattern of the family, patterns of education, housing, health physical, the management of the home, pattern recreation, crime, and satisfaction of life. At the stage of this, the potential that is inherent in the self- society should be known first advance and analysed in order to maximize the step further that the purpose of forming a community of craftsmen batik

\subsubsection{Aims}

Based on the results of observations, interviews, and FGD, with the objectives of community development program planning are:

3.4.2.1. It can provide an understanding and awareness of the public about the fundamental techniques of participation in the program development community in the study of the case of the Tampo Village is the formation of a community of craftsmen batik

3.4.2.2 Understand the formulation of objectives formation program

3.4.2.3. Collect some input for the implementation of the community development program properly.
3.4.2.4 Cultivate the ability of society to know the problems that occur in the vicinity and describe their needs.

Whereas for the model community of craftsmen batik 's, can be formulated according to the needs. In line large can be written as follows:

1. Minimizing price competition for batik production among craftsmen

2. Routine conduct a meeting to discuss the challenges of the production of batik in the future

3. Increase innovation in terms of batik motifs to attract more market attention.

\subsubsection{Preparation and development of participatory planning}

At this stage the community compiles a planning pattern for the formation of a batik craftsman community. This stage is also referred to as the planning stage of program preparation and the goals of establishing a batik craftsman community. In preparing for community empowerment, it is necessary to pay attention to the equality of citizens in terms of potential and habits so that in implementing the community empowerment process an equal position can be created in the community [8]. Thus there will be no differentiation which will later create divisions in the community and community empowerment programs.

\subsubsection{Implementation}

Implementation here is a community of artisans. Batik already knows things about any course that has been designed and the action they are implementing in the program. Programs that can be done are with a more lots making programs themed cultural introduction to batik and marketing. Like making a batik festival. Besides functioning as a cultural introduction, it can also be used to market products.

\subsubsection{Evaluation}

Evaluation is carried out if in 1 program stage it has been implemented. In this evaluation, real data must be collected about programs that were implemented and not implemented. For a program that has been implemented with good can formulate a strategy to be able to increase the capacity of the program. For a program that has not been done by either made into material evaluation in order to think about how to solve the problem.

\subsection{Prospects of batik craftsmen community}

Because the purpose of the establishment of community artisan's batik is to avoid the price competition are not healthy between craftsmen batik, and can add to the innovation of new that can make the marketing of products batik become much higher, then the prospects for craftsmen and society to start a business of batik have become much higher. Prospects 
are not only to improve the conditions of the economic community, but in terms of the other is from the angle of view of the program the village staff is very suitable carried out in the Tampo Village. Tampo Village as a village which is famous with the production of batik was attempting to develop a village tour batik and with the formation of a community of craftsmen batik This could encourage businesses Tampo Village to realize the Tampo Village become village tourist batik. Community local there are those individuals, who form the organization and mutual cooperation and mutually dependent among which one with another [1]. Besides that, the prospects of a development-based society is one of mechanisms of distribution of assistance with establishment more quickly and evenly [9].

\section{CONCLUSION}

Batik as a form of small and medium-sized community business has contributed significantly to Indonesia's economic growth since 2016. Most batik industries have been developed by the local community as a means of introducing regional culture and improving the community's economy. Because they are closer to the community, a community is needed for batik craftsmen so that batik is seen as an economic prospect that can increase the welfare of the group. Therefore, we need a model to support community participation, namely in the form of a batik craftsman community. The aim is to minimize the price competition among craftsmen and increase the innovation of batik motifs to make it more attractive in the market without eliminating regional cultural elements that are contained in certain batik motifs in each region.

\section{REFERENCES}

[1] S. L. Cummings, "Community economic development as progressive politics: Toward a grassroots movement for economic justice," Stanford Law Rev., vol. 54, no. 3, pp. 399-493, 2001, doi: 10.2307/1229464.

[2] B. Gatut and V. Aryanto, "Batik Industry of Indonesia: the Rise, Fall and Prospects," Stud. Bus. Econ., vol. 5, no. 3, pp. 156-170, 2010.

[3] N. Maninggar, D. Hudalah, R. Sutriadi, and T. Firman, "Low-tech industry, regional innovation system and inter-actor collaboration in Indonesia: The case of the Pekalongan batik industry," Asia Pac. Viewp., vol. 59, no. 3, pp. 249-264, 2018, doi: 10.1111/apv.12193.

[4] S. Hadi, I. Qiram, and G. Rubiono, "Exotic Heritage from Coastal East Java of Batik Bayuwangi," IOP Conf. Ser. Earth Environ. Sci., vol. 156, no. 1, 2018, doi: 10.1088/17551315/156/1/012018.
[5] D. Vanleene, J. Voets, and B. Verschuere, "The co-production of public value in community development: can street-level professionals make a difference?," Int. Rev. Adm. Sci., vol. 86, no. 3, pp. 582-598, 2020, doi: $10.1177 / 0020852318804040$.

[6] C. Blickem et al., "What is Asset-Based Community Development and How Might It Improve the Health of People With Long-Term Conditions? A Realist Synthesis," SAGE Open, vol. 8, no. 3, pp. 15-21, 2018, doi: $10.1177 / 2158244018787223$.

[7] W. S. Lung-Amam and C. Dawkins, "The power of participatory story mapping: Advancing equitable development in disadvantaged neighbourhoods," Community Dev. J., vol. 55, no. 3, pp. 473-495, 2020, doi: $10.1093 /$ cdj/bsy064.

[8] M. O. Adedokun and G. M. Kayode, "Local Leadership Styles and Community Development: A Study of the Irasa Community of Ado-Ekiti, Nigeria," Budapest Int. Res. Critics Linguist. Educ. J., vol. 2, no. 4, pp. 2731, 2019, doi: 10.33258/birle.v2i4.469.

[9] G. Mansuri and V. Rao, "Community-based and -driven development: A critical review," World Bank Res. Obs., vol. 19, no. 1, pp. 1-39, 2004, doi: 10.1093/wbro/lkh012. 